\title{
PENERAPAN MODEL PEMBELAJARAN SCRAMBLE UNTUK MENINGKATKAN HASIL BELAJAR SISWA PADA MATA PELAJARAN AKUNTANSI KEUANGAN
}

\author{
(Penelitian Tindakan Kelas XI AK SMK 1 Pasundan Kota Serang)
}

\author{
Oleh: Nely Hartika ${ }^{1)}$, Restu Ayu Ismayanti ${ }^{2)}$ \\ Universitas Banten Jaya \\ Serang, Indonesia \\ Nely.hartika@gmail.com,rhestuayu11@gmail.com
}

\begin{abstract}
This study was aimed to find out how the application of scramble learning model in class XI SMK Pasundan 1 Serang City and found out how the learning outcomes of students. This research used classroom action research method consisting of two cycles. Each cycle consists of four stages: planning, execution, observation and reflection. The subjects of this study were students of class XI SMK Pasundan 1 Serang City with 39 students and subject teacher as a team of collaborator.The results of this study indicateed that the scramble learning model could improve student learning outcomes because in the first cycle, from 39 students who managed to score above the KKM was 79,35\% or 33 students, while in the second cycle increased to $90,25 \%$.
\end{abstract}

Keywords: Learning model, Scramble, Learning result.

\section{PENDAHULUAN}

Pendidikan merupakan proses yang sangat menentukan kemajuan dan perkembangan individu masyarakat suatu bangsa.

Berdasarkan kenyataan yang ada, Indonesia dibandingkan dengan Negara lain yang telah memiliki kualitas pendidikan yang baik, tampak jelas adanya perbedaan kualitas kehidupan. Pendidikan di Indonesia saat ini masih terbilang rendah. Dalam hal ini agar kualitas kehidupan bisa menjadi lebih baik adalah dengan cara meningkatkan kualitas pendidikan.
Menurut Undang-Undang No 20 Tahun 2003 tentang Sistem Pendidikan Nasional menyebutkan bahwa :

Pendidikan Nasional berfungsi mengembangkan kemampuan dan membentuk watak serta peradaban bangsa yang bermanfaat dalam rangka mencerdaskan kehidupan bangsa. Pendidikan bertujuan untuk mengembangkan potensi peserta didik agar menjadi manusia yang beriman dan bertakwa kepada Tuhan yang Maha Esa, Berahlak mulia, Sehat, Berilmu, Kreatif, Mandiri, dan menjadikan warga Negara yang demokrasi serta bertanggung jawab. (UU No.20 tahun 2003) 
Banyak sekali faktor-faktor yang menyebabkan rendahnya kualitas pendidikan, faktor-faktor yang menyebabkan tidak tercapainya kualitas pendidikan yang baik menjadi persoalan bagi bidang pendidikan, setelah mengetahui persoalan pendidikan tersebut maka harus dipikirkan bagaimana penyelesaiannya agar kualitas pendidikan bisa menjadi lebih baik.

Permasalahan yang timbul saat ini khususnya di SMK Pasundan 1 Kota Serang kelas XI Akuntansi adalah hasil belajar siswa yang masih rendah.

Hal ini terjadi karena kegiatan pembelajaran monoton dan model yang diterapkan tidak cocok dengan materi yang diajarkan sehingga hasil belajar peserta didik rendah hal ini dikarenakan proses pembelajaran yang masih berfokus pada guru sebagai sumber pengetahuannya,dan model pembelajaran ceramah dan konvensional sebagai pilihan utama pembelajaran.

Salah satu cara yang dapat digunakan yakni membuat pembelajaran bervariasi. Penggunaan berbagai metode, media dan inovasi pendidikan lain dapat dilakukan suasana pembelajaran berbeda yakni menggunakan kooperatif learning.

Koopratif learning dapat memberi kesempatan kepada siswa untuk dapat aktif dalam proses pembelajaran. Sehingga siswa dapat berpikir sendiri. Guru tidak lagi berperan sebagai pusat pengetahuan, namun siswa dapat mengembangkan pengetahuannya sendiri. Dalam koopretaif learning, salah satu model yang digunakan adalah Model Pembelajaran Scramble

Menurut Robet B. Taylor: (dalam Huda, 2013:303), scramble merupakan salah satu metode pembelajaran yang dapat meningkatkan konsentrasi dan kecepatan berfikir siswa. Metode ini mengharuskan siswa untuk menggunakan otak kanan dan juga otak kiri.

Istilah scramble berasal dari Bahasa Inggris yang diterjemahkan dalam Bahasa Indonesia berarti perebutan, pertarungan, perjuangan.

Menurut Widodo (2009: 2). model pembelajaran scramble merupakan suatu model pembelajaran dengan membagikan lembar soal dan lembar jawaban yang di sertai dengan alternatif jawaban yang tersedia namun dengan susunan yang acak dan siswa bertugas mengkoreksi (membolak balik huruf) jawaban. Siswa diharapkan mampu mencari jawaban yang tepat dan benar.Sesuai dengan sifat jawabannya Scramble terdiri atas bermacam-macam bentuk yakni;

1. Scramble kata: yakni sebuah permainan menyusun kata-kata dan huruf-huruf yang telah dikacaukan letaknya sehingga membentuk suatu kata tertentu yang bermakna misalnya: 
Utang $=$ Piutang

2. Scramble kalimat: yakni sebuah permainan menyusun kalimat dari katakata acak. Bentuk kalimat hendaknya logis, bermakna, tepat, dan benar. Contohnya:

Bertambah-di-modal-debit-di-kaskredit-bertambah $=$ Kas bertambah di debit, Modal bertambah di kredit

3. Scramble wacana : yakni sebuah permainan menyusun wacana logis berdasarkan kalimat-kalimat acak. Hasil sususan wacana hendaknya logis dan juga bermakna.

Menurut Huda (2013:304) langkahlangkah model pembelajaran kooperatif tipe Scramble sebagai berikut :

1. Guru menyajikan materi sesuai topik.

2. Guru membagikan lembar kerja dengan jawaban yang diacak susunannya.

3. Guru memberi durasi tertentu untuk pengerjaan soal,

4. Siswa mengerjakan soal berdasarkan waktu yang ditentukan guru.

5. Guru mengecek durasi waktu sambil memeriksa pekerjaan siswa.

6. Jika waktu pengerjaan soal sudah habis, siswa wajib mengumpulan lembar pekerjaan atau lembar jawaban kepada guru.
7. Guru melakukan penilaian baik di kelas maupun dirumah.

8. Guru memberikan apresiasi dan recognition kepada siswa siswa yang berhasil, dan memberi semangat kepada siswa yang cukup berhasil menjawab dengan cepat dan benar.

Menurut Huda (2013:305) model koperatif tipe scramble memiliki kelebihan dan kekurangan.

1. Setiap anggota kelompok bertanggung jawab atas segala sesuatu yang di kerjakan dalam kelompoknya, setiap anggota kelompok harus mengetahui bahwa semua anggota kelompok mempunyai tujuan yang sama, setiap kelompok harus membagi tugas dan bertanggung jawab yang sama diantara anggota kelompoknya, setiap kelompok akan dikenai evaluasi, setiap kelompok berbagi kepemimpinan dan membutuhkan keterampilan untuk belajar bersama selama proses belajarnya, dan setiap anggota kelompok akan diminta mempertanggung jawabkan secara individual materi yang ditangani dalam kelompok.

2. Model pembelajaran ini akan memungkinkan siswa untuk belajar sambil bermain. Mereka dapat berkreasi sekaligus belajar berpikir, 
mempelajari sesuatu secara santai dan tidak membuat stress atau tertekan.

3. Selain untuk menimbulkan kegembiraan dan melatih keterampilan tertentu, model ini juga daapat menumbuhkan rasa solidaritas dalam kelompoknya.

4. Materi yang diberikan melalui model permainan ini biasanya mengesankan dan sulit untuk dilupakan.

5. Sifat kompetitif dalam model ini dapat mendorong siswa berlomba-lomba untuk maju.

Sedangkan kekurangan dari metode ini adalah:

1. Pembelajaran ini terkadang sulit dalam merencanakan, oleh karena terbentur dengan kebiasaan siswa dalam belajar.

2. Terkadang dalam mengimplementasikannya, memerlukan waktu yang panjang sehingga guru sulit menyelesaikannya dengan waktu yang telah ditentukan.

3. Selama kriteria keberhasilan belajar ditentukan oleh kemampuan siswa menguasai materi pelajaran, maka pembelajaran ini akan sulit di implementasikan oleh guru.

4. Metode bermain seperti ini biasanya menimbulkan suara gaduh. Hal tersebut jelas akan mengganggu kelas yang berdekatan
Dari beberapa keterbatasan tersebut, alasan penulis memilih melakukan penelitian dengan model pembelajaran scramble karena keunggulan utama dari metode ini adalah dorongan kepada siswa untuk bertanggung jawab dan bekerjasama. Rasa tanggung jawab bahwa keberhasilan kelompok tergantung kepada kerja kerasnya, menyebabkan siswa belajar lebih tekun dan berdiskusi lebih efektif sehingga hasil belajar siswa meningkat.

\section{METODE PENELITIAN}

Penelitian ini dilakukan di kelas XI AK SMK Pasundan 1 Kota Serang untuk mata pelajaran akuntansi keuangan. Waktu yang digunakan oleh peneliti untuk melakukan penelitian ini pada Semester Genap Tahun Pelajaran 2016/2017 di mulai pada bulan April 2017.

Dalam penelitian ini peneliti berperan dalam perencanaan kegiatan pembelajaran dan berkolaborasi dengan guru mata pelajaran Akuntansi keuangan. Peneliti juga mengawasi kegiatan pembelajaran dan meneliti proses penerapan Model Pembelajaran Scramble selama proses pembelajaran berlangsung.

Penelitian ini menggunakan desain penelitian tindakan kelas. Menurut Arikunto(2013:131) pelaksanaan PTK terdiri dari empat tahap yaitu: (1) 
Perencanaan, (2) Pelaksanaan, (3)

Observasi (4) Refleksi.

Gambar 1

Siklus PTK

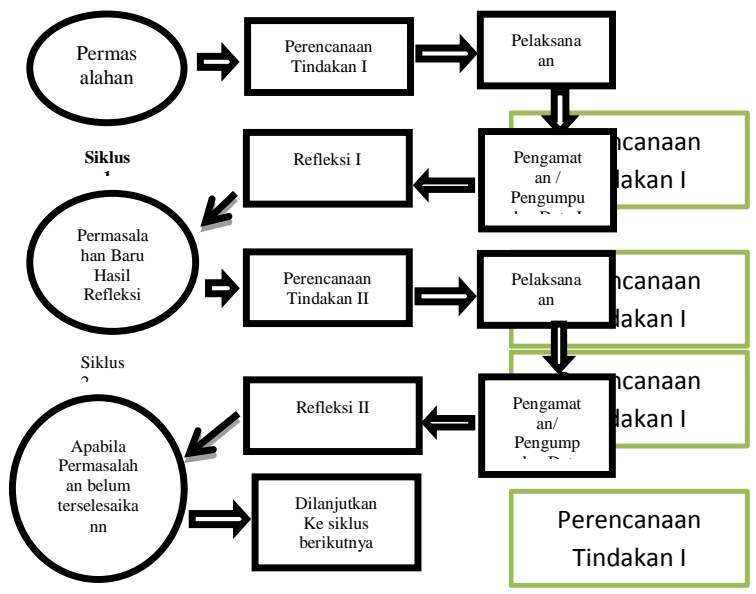

Gb. 1. Alur Penelitian Tndakan Kelas

(Arikunto, 2012: 74)

Prosedur dalam penelitian ini terdiri dari tahapan yang ada dalam setiap siklus yang terdiri dari beberapa tahap kegiatan yaitu

1. Tahap perencanaan

Kegiatan yang dilakukan oleh peneliti pada tahap ini yaitu :

a. Berdiskusi dengan sekolah, terutama guru mata pelajaran Akuntansi keuangan tentang kesulitan yang dialami siswa

b. Menentukan tujuan pembelajaran beserta perangkat pembelajaran yang menggunakan model scramble hingga proses evaluasi.
2. Pelaksanaan

Tindakan penelitian ini dilakukan pada siswa kelas XI Ak SMK Pasundan 1 Kota Serang. Tindakan pelaksanaan terdiri dari beberapa siklus. Siklus akan di hentikan jika tujuan telah tercapai.

3. Observasi

Pada tahap ini dilakukan pengamatan terhadap kegiatan pembelajaran yang berlangsung dengan menggunakan format pengamatan observasi.

4. Refleksi

Refleksi dilakukan dengan menyusun laporan dari semua kegiatan yang telah dilaksanakan selama penelitian. Sehingga peneliti dapat menentukan hal-hal yang akan dilakukan untuk perbaikan. Keputusan untuk menghentikan atau melanjutkan siklus ditentukan dengan hasil yang diperoleh. Siklus dihentikan jika pembelajaran yang dilakukan sudah sesuai dengan rencana dan telah mampu meningkatkan penguasaan konsep belajar siswa. (Arikunto: 2013).

Data dikumpulkan dengan cara:

1. Tes

2. Observasi

3. Wawancara

4. Dokumentasi dengan instrumen pengumpulan data berupa:

1. Tes/Lembar Tes 
2. Format Observasi

\section{Dokumentasi/Daftar Dokumentasi}

Menurut Hamalik (2003:166), hal-hal yang harus diperhatikan untuk mengetahui keberhasilan siswa memahami suatu konsep, yaitu :

1. Dapat menyebutkan contoh konsep

2. Dapat menyatakan ciri-ciri konsep

3. Dapat memilih dan membedakan antara contoh konsep dengan yang bukan konsep

4. Dapat memecahkan masalah yang berkenaan dengan konsep

Adapun Indikator Keberhasilan yang diharapkan dalam penelitian ini adalah hasil belajar siswa pada mata pelajaran akuntansi keuangan dapat meningkat. ditunjukkan dengan pencapaian hasil belajar pada siswa dengan KKM yang telah ditetapkan sekolah.

Sebagai tolak ukur meningkatnya partisiasi belajar untuk mencapai hasil belajar siswa yang maksimal pada mata pelajaran akuntansi keuangan ,melalui model pembelajaran Scramble dapat dilihat dari:

1. Partisipasi belajar siswa untuk hasil belajar yang baik $80 \%$.

2. Dilihat dari kriteria ketuntasan maksimal (KKM) yatu 75 pada seluruh siswa.

Teknik analisis data yang digunakan dalam penelitian ini adalah analisis data deskripitif kuantitatif. Dalam penelitian ini, peneliti melakukan kolaborasi bersama guru mata pelajaran akuntansi keuangan kelas XI SMK Pasundan 1 Kota Serang

1. Peneliti dan guru mata pelajaran mengidentifikasi permasalahan

2. Peneliti dan guru membuat skenario pembelajaran.

3. Peneliti membuat pre - test dan lembar observasi

4. Peneliti bersama guru akuntansi menentukan indikator keberhasilan yang ingin dicapai.

5. Peneliti menilai dan menganalisis penguasaan materi belajar siswa.

\section{HASIL PENELITIAN DAN} PEMBAHASAN

Penelitian ini dilaksanakan dalam dua siklus. Siklus I dan siklus II dilaksanakan dalam dua kali pertemuan. Adapun kegiatan pembelajaran pada siklus I adalah sebagai berikut:

\section{Perencanaan}

Kegiatan perencanaan pada siklus 1 dilaksanakan pada hari Senin, 10 April 2017 di ruang guru SMK Pasundan 1 Kota Serang. Guru bersama peneliti mendiskusikan rancangan kegiatan yang akan dilakukan dalam penelitian ini. Peneliti mengungkapkan kepada guru bahwa peneliti menemukan permasalahan di dalam kelas pada saat Kegiatan Belajar 
Mengajar (KBM) berlangsung yaitu peserta didik mengalami jenuh dan kurang aktif dalam mengikuti pembelajaran sehingga hasil belajar peserta didik masih banyak yang di bawah KKM. Kemudian disepakati bahwa pelaksanaan tindakan siklus 1 akan dilaksanakan dalam 2 kali pertemuan, yaitu hari Senin dan Rabu ( 17 dan 19 April 2017).

Peneliti bersama Guru mendiskusikan Rencana Pelaksanaan Pembelajaran (RPP) dengan menggunakan model pembelajaran Scramble yang sebelumnya sudah direncanakan oleh peneliti. Kemudian peneliti menyusun instrument penelitian berupa tes dan non tes. Instrument tes untuk mengetahui hasil belajar siswa dengan dilihat dari hasil evaluasi, sedangkan instrument non tes bertujuan untuk mengetahui keaktifan siswa selama mengikuti proses pembelajaran berlangsung dengan dilihat dari hasil observasi.

\section{Pelaksanaan}

Dalam pelaksanaan tindakan pada siklus 1 peneliti melaksanakan pembelajaran dengan menggunakan model pembelajaran Scramble pada mata pelajaran akuntansi keuangan, pelaksanaan tindakan merupakan implementasi dari hasil rencana tindakan yang telah disusun pada tahap perencanaan. Kegiatan pelaksanaan siklus 1 dilaksanakan pada tanggal 17,dan 19 April 2017. Kegiatan yang akan dilaksanakan sesuai dengan perencanaan pembelajaran yang disusun. Materi pembelajaran diberikan dalam tiga kali pertemuan dengan alokasi waktu masing-masing 3 JP pada setiap pertemuan terdiri dari beberapa tahap yaitu pendahuluan, inti, dan penutup.

Pertemuan pertama dilakukan pada hari Senin tanggal 17 April 2017 pukul 09.15 WIB dikelas XI AK. pembelajaran diawali dengan materi mempersiapkan pengelolaan kartu hutang dengan tujuan pembelajaran agar siswa dapat dengan mudah mengetahui bagaimana cara menguraikan prosedur penanganan utang dan juga dapat mengelompokan utang.

a. Guru memasuki kelas dengan mengucapkan salam.

b. Salah satu siswa menyiapkan dan memimpin doa bersama.

c. Guru mengabsen kehadiran siswa,

d. Guru melakukan apersepsi, untuk mengetahui seberapa besar siswa memahami materi yang akan diberikan.

e. Guru memberikan kesem-patan kepada siswa untuk bertanya mengenai materi sebelumnya yang telah dipelajari.

f. Guru memulai menjelaskan materi dengan menjelaskan tentang mempersiapkan pengelolaan kartu hutang. Dan kemudian guru memberikan kesempatan kepada siswa 
untuk menanyakan materi yang belum dipahami.

g. Selanjutnya guru menjelas-kan tantang pengelompokan utang.. Kemudian guru memberikan kesempatan kepada siswa tentang materi yang belum dipahami.

h. Guru menjelaskan tentang model pembelajaran yang akan digunakan yaitu model pembelajaran Scramble, dimana siswa akan belajar secara kelompok.

i. Guru membagi siswa kedalam 6 kelompok dengan masing-masing kelompok terdiri dari 6-7siswa.

j. Setiap kelompok menem-pati tempat duduk secara berkelompok

k. Guru menyiapkan bahan materi, kemudian kalimat-kalimat yang terdapat dalam wacana tersebut di keluarkan kedalam kartu-kartu kalimat.

1. Guru menyediakan soal dan jawaban dalam bentuk kartu dan di acak nomor urutnya disesuaikan dengan materi ajar teks dimana telah dibagikan sebelumnya. Kemudian soal dan jawaban dalam bentuk kartu tersebut dibagikan.

m. Siswa mengerjakan soal dan mencari kartu soal untuk jawaban yang cocok pada kelompok masing-masing, dimana sebelumnya jawaban telah disiapkan secara acak. n. Siswa di haruskan dapat menyusun kata jawaban yang telah tersedia dalam waktu yang di tentukan.

o. Kerja kelompok berjalan dengan lancar, namun ada beberapa siswa yang masih mengandalkan kemampuan temannya, dan dia tidak ikut berpartisipasi dalam mengerjakan tugas yang sudah dibagikan oleh ketua kelompok. Namun guru selalu berkeliling untuk mengawasi jalannya kerja kelompok. Mulailah siswa semakin aktif dan begitu tekun dalam mengerjakan tugasnya.

p. Jam pelajaran akan segera habis, tetapi masih banyak kelompok yang belum selesai, maka guru memberikan kesempatan untuk dikerjakan pada pertemuan ke-dua.

q. Guru menutup pertemuan.

Pertemuan kedua dalam siklus 1 dilakukan pada hari Rabu, 19 April 2017 pukul 09.15.

a. Guru memasuki kelas dengan mengucapkan salam.

b. Salah satu siswa menyiap-kan dan memimpin doa bersama.

c. Guru mengabsen kehadiran siswa.

d. Guru melakukan apersepsi, untuk mengetahui seberapa besar siswa memahami materi yang akan diberikan. 
e. Guru memberikan kesem-patan kepada siswa untuk bertanya mengenai materi sebelumnya yang telah dipelajari.

f. Siswa menanyakan tentang apa saja yang termasuk hutang jangka pendek.

g. Guru memberikan kesem-patan kepada salah satu siswa untuk menjawab pertanyaan temannya, dan kemudian menyimpulkan dan menjelaskan kembali jawaban yang diberikan oleh temannya.

h. Guru memulai pembela-jaran dengan mengatur tempat duduk siswa untuk berdekatan dengan kelompoknya.

i. Siswa melanjutkan mengerjakan tugas kelompok pertemuan sebelumnya.

j. Kerja kelompok berjalan dengan lancar dan guru selalu mengawasi dan menanyakan kesulitan dalam mengerjakannya.

k. Setelah semua kelompok telah selesai ngerjakan, salah satu kelompok mempersentasikan hasil jawaban yang cocok dengan soal yang diberikan.

1. Siswa diberikan kesem-patan untuk sesi tanya jawab.

m. Guru menyimpulkan dan menjelaskan kembali jawaban yang telah dijawab oleh siswa.

n. Guru meminta kepada semua kelompok untuk mengumpulkan hasil kerja kelompoknya. o. Guru meminta siswa untuk kembali ketempat duduk asal dan merapihkan tempat duduknya.

p. Sebelum menutup perte-muan, guru menyimpulkan dan mengoreksi hasil kerja kelompok, dan memberikan kesempatan kepada siswa untuk bertanya.

q. Guru memberitahu skenario pembelajaran pada pertemuan berikutnya.

r. Guru menutup pertemuan.

Adapun data hasil Pre test dan post test di peroleh dari dilakukannya siklus 1 dapat di lihat pada tabel berikut.

Tabel .1 Nilai Pre test \& Post test

\begin{tabular}{|c|c|c|c|}
\hline No & Nama & Pre Test & Post Test \\
\hline 1 & AAS & 80 & 75 \\
\hline 2 & $\mathrm{CS}$ & 80 & 60 \\
\hline 3 & DAS & 75 & 80 \\
\hline 4 & DS & 75 & 80 \\
\hline 5 & EY & 80 & 75 \\
\hline 6 & FR & 75 & 85 \\
\hline 7 & $\mathrm{HF}$ & 75 & 85 \\
\hline 8 & HL & 75 & 70 \\
\hline 9 & HR & 80 & 85 \\
\hline 10 & IH & 75 & 85 \\
\hline 11 & LTP & 75 & 80 \\
\hline 12 & LR & 75 & 85 \\
\hline 13 & LF & 75 & 80 \\
\hline 14 & MAE & 80 & 80 \\
\hline 15 & MA & 65 & 65 \\
\hline 16 & MAU & 80 & 85 \\
\hline 17 & MMS & 75 & 70 \\
\hline
\end{tabular}




\begin{tabular}{|c|c|c|c|}
\hline 18 & MAF & 80 & 80 \\
\hline 19 & MZI & 70 & 75 \\
\hline 20 & MU & 80 & 70 \\
\hline 21 & NM & 75 & 85 \\
\hline 22 & NUR & 70 & 85 \\
\hline 23 & NUH & 75 & 80 \\
\hline 24 & PIP & 80 & 85 \\
\hline 25 & RH & 75 & 80 \\
\hline 26 & RO & 70 & 85 \\
\hline 27 & $\mathrm{RS}$ & 75 & 85 \\
\hline 28 & SA & 75 & 90 \\
\hline 29 & SAN & 60 & 80 \\
\hline 30 & SB & 80 & 75 \\
\hline 31 & SM & 75 & 80 \\
\hline 32 & SMU & 75 & 85 \\
\hline 33 & SR & 75 & 80 \\
\hline 34 & SW & 60 & 70 \\
\hline 35 & SWA & 70 & 80 \\
\hline 36 & SU & 80 & 90 \\
\hline 37 & VR & 75 & 75 \\
\hline 38 & YS & 70 & 80 \\
\hline \multirow[t]{3}{*}{39} & DS & 70 & 75 \\
\hline & JUMLAH & 2.91 & 3.095 \\
\hline & $\begin{array}{l}\text { RATA- } \\
\text { RATA }\end{array}$ & 74,61 & 79,35 \\
\hline
\end{tabular}

Rata-rata nilai kelas pre test

$=$ Jumlah Nilai Akhir Yang Diperoleh

Siswa/Jumlah Siswa

$=\quad 2.910 / 39$

$=\quad 74.61$

Rata-rata nilai kelas post test

$=$ Jumlah Nilai Akhir Yang Diperoleh

Siswa/Jumlah Siswa

$$
\begin{array}{ll}
= & 3.095 / 39 \\
= & 79,35
\end{array}
$$

Tabel 2. Kriteria keberhasilan belajar siswa

\begin{tabular}{cc}
\hline Presentase & Kategori \\
\hline $91-100$ & Sangat baik \\
$81-90$ & Baik \\
$75-80$ & Cukup \\
$61-74$ & Kurang
\end{tabular}

50-60 Sangat kurang

Berdasarkan tabel hasil pre test dan post test di atas, pada pelaksanaan siklus I siswa sudah mencapai Kriteria Ketuntasan Minimal (KKM) yang ditetapkan yaitu 75 dengan nilai rata-rata kelas pre test sebesar 74,61 yang masuk dalam kategori kurang, ketuntasan siswa pada awal pre test perlu ditingkatkan untuk mencapai keberhasilan.

Berdasarkan hasil post test siklus I di atas, jumlah siswa yang mencapai ketuntasan belajar sebanyak 33. Nilai ratarata post test sebesar 79,35 yang berada pada kriteria baik.

Rumus Menghitung Ketuntasan Belajar

$$
\begin{aligned}
\mathrm{P} & =\frac{\sum \mathbf{P}}{\sum \mathbf{N}} \times 100 \% \\
\mathrm{P} & =\underline{33} \times 100 \% \\
& 39 \\
= & 85 \%
\end{aligned}
$$

Keterangan :

$\mathrm{P}=$ Ketuntasan belajar

$\sum \mathrm{P}=$ Jumlah siswa yang tuntas belajar

$\sum \mathrm{N}=$ Jumlah siswa

$100 \%=$ Bilangan tetap

3. Observasi 
Pada tahap observasi, alat ukur yang digunakan adalah lembar observasi guru dan siswa Peneliti melakukan pengamatan proses pembelajaran dengan menggunakan media pembelajaran Scramble dikelas XI AK. Berdasarkan hasil pengamatan terhadap pelaksanaan proses pembelajaran akuntansi keuangan. Berikut hasil lembar kegiatan observasi pada siklus I:

Tabel 3. Hasil lembar kegiatan observasi siklus 1

\begin{tabular}{llll}
\hline \multirow{2}{*}{ No Aspek yang diamati } & \multicolumn{3}{c}{ Skala penilaian } \\
\cline { 2 - 4 } & 1 & 2 & 3
\end{tabular}

Siswa memperhatikan

1 guru pada proses

KBM berlangsung

Siswa antusias pada

2 proses $\mathrm{KBM}$

berlangsung

Siswa mau bertanya

pada saat merasa

3 kurang paham

mengenai materi yang

diajarkan

Siswa mampu

4 mengerjakan soal

yang diberikan guru

Siswa antusias

mempelajari materi

5 menggunakan media

pembelajaran

Scramble

Siswa melakukan

6 diskusi dan

memecahkan masalah

${ }_{7}$ Siswa bekerjasama

dengan kelompok
Siswa teliti dalam

8 menyelesaikan tugas

yang diberikan guru

Siswa lebih

9 bersemangat

mengikuti KBM

Siswa lebih aktif dan

10 jeli dalam proses

KBM

$\begin{array}{llll}\text { Jumlah } & 1 & 14 & 6\end{array}$

Sumber: Data yang diolah 2017

Penilaian pada observasi menggunakan skala likert yaitu :

1. Skor 1 : Kurang

2. Skor 2 : Cukup

3. Skor 3 : Baik

Kriteria Penilaian :

$81 \%-100 \%=$ Sangat baik

$71 \%-80 \%=$ Baik

$61 \%-70 \%=$ Cukup

$51 \%-60 \%=$ Kurang

Penilaian:

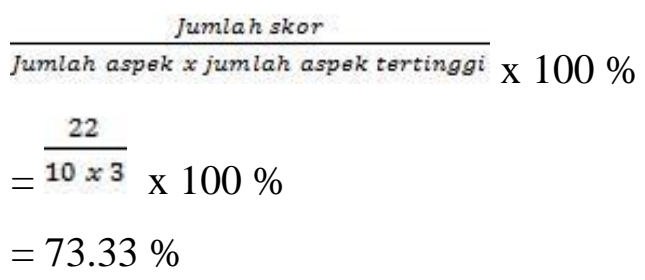

Berdasarkan hasil pengamatan aktivitas guru, aktivitas guru pada siklus 1 73\% yaitu berada pada kriteria B ( Baik), melakukan pengelolaan kelas dengan baik dimulai dengan pengabsenan dan pemberian materi.

4. Refleksi 
Setelah dilakukan tindakan dan pengamatan atas tindakan pada pembelajaran di dalam kelas, didapatkan hasil belajar siswa yang diatas KKM sebanyak $77 \%$ atau 30 siswa, sedangkan $23 \%$ atau 9 siswa masih berada dibawah $\mathrm{KKM}$, hal ini belum tercapai indikator yang telah direncanakan.

Selanjutnya dilakukan refleksi atas segala kegiatan yang dilakukan pada siklus 1. Peneliti melakukan analisis sebagai berikut:

a. Kelemahan guru dalam siklus 1:

1) Guru kurang memotivasi atau melakukan pendekatan kepada siswa yang lambat dalam memahami pelajaran dan siswa yang kurang bersosialisasi kepada teman-temannya. Sehingga mereka hanya mengandalkan teman dekatnya saja dan belum bisa ikut mengungkapkan pendapat dalam mengerjakan tugas kelompoknya.

2) Guru belum sepenuhnya dapat menjangkau satu persatu peserta didik pada saat proses diskusi berlangsung.

3) Guru kurang memberikan penghargaan kepada siswa yang mampu menyelesaikan tugas dengan benar.

b. Kelemahan siswa dalam siklus 1:
1) Siswa masih belum sungguhsungguh untuk mengikuti pelajaran pengantar keuangan dan akuntansi. Dikarenakan masih bingung dalam memahami materi yang dipelajari.

2) Masih ada siswa yang merasa malas dan bingung untuk bergabung dengan kelompoknya.

3) Siswa baru akan ikut serta dalam diskusi dan mengerjakan tugasnya apabila guru melakukan pendekatan. Oleh karena itu, peran guru sebagai fasilitator sangatlah penting dalam kegiatan belajar mengajar.

\section{Siklus II}

1. Perencanaan

Kegiatan perencanaan pada siklus II dilaksanakan pada hari Sabtu, 24 April 2017 di ruang guru SMK 1 Pasundan Kota Serang. Guru bersama peneliti mendiskusikan rancangan kegiatan yang akan dilakukan dalam penelitian ini. Peneliti mengungkapkan bahwa kepada guru bahwa peneliti menemukan kelemahan-kelemahanyang terjadi pada pelaksanaan siklus I. Kemudian disepakati bahwa pelaksanaan tindakan siklus II akan dilaksanakan dalam 2 kali pertemuan, yaitu hari Senin dan Rabu ( 01 dan 03 Mei 2017).

Peneliti bersama Guru mendiskusikan Rencana Pelaksanaan 
Pembelajaran (RPP) dengan menggunakan media pembelajaran monopoli yang sebelumnya sudah direncanakan oleh peneliti. Kemudian peneliti menyusun instrument penelitian berupa tes dan non tes.

Instrument tes untuk mengetahui hasil belajar siswa dengan dilihat dari hasil evaluasi, sedangkan instrument non tes bertujuan untuk mengetahui keaktifan siswa selama mengikuti proses pembelajaran berlangsung dengan dilihat dari hasil observasi.

2. . Pelaksanaan

Pada siklus II, kegiatan siklus II dilaksanakan pada hari Senin, 01 Mei 2017 dan Rabu, 03 Mei 2017.

Pertemuan pertama dilakukan pada hari Senin tanggal 01 mei 2017 pukul 09.15 WIB dikelas XI AK. pembelajaran diawali dengan materi mempersiapkan pengelolaan kartu hutang dengan ujuan pembelajaran agar siswa dapat dengan mudah mengetahui bagaimana cara menguraikan prosedur penanganan utang dan juga dapat mengelompokan utang.
a. Guru memasuki kelas dengan mengucapkan salam.
b. Salah satu siswa menyiapkan dan memimpin doa bersama.
c. Guru mengabsen kehadiran siswa,

d. Guru melakukan apersepsi, untuk mengetahui seberapa besar siswa memahami materi yang akan diberikan.

e. Guru memberikan kesempatan kepada siswa untuk bertanya mengenai materi sebelumnya yang telah dipelajari.

f. Guru memulai menjelaskan materi dengan menjelaskan tentang mempersiapkan pengelolaan kartu hutaang. Dan kemudian guru memberikan kesempatan kepada siswa untuk menanyakan materi yang belum dipahami.

g. Selanjutnya guru menjelaskan tantang pengelompokan utang.. Kemudian guru memberikan kesempatan kepada siswa tentang materi yang belum dipahami.

h. Guru menjelaskan tentang model pembelajaran yang akan digunakan yaitu model pembelajaran Scramble, dimana siswa akan belajar secara kelompok.

i. Guru membagi siswa kedalam 6 kelompok dengan masing-masing kelompok terdiri dari 6-7siswa.

j. Setiap kelompok menempati tempat duduk secara berkelompok.

k. Guru menyiapkan suatu materi, kemudian dibuat kalimat yang terdapat dalam materi tersebut kedalam kartukartu kalimat.

1. Guru menyediakan soal dan jawaban dalam bentuk kartu dan di acak nomor 
urutnya disesuaikan dengan materi ajar teks dimana telah dibagikan sebelumnya. Kemudian soal dan jawaban dalam bentuk kartu tersebut dibagikan.

m. Siswa mengerjakan soal dan mencari kartu soal untuk jawaban yang cocok pada kelompok masing-masing, dimana sebelumnya jawaban telah disiapkan secara acak.

n. Siswa di haruskan dapat menyusun kata jawaban yang telah tersedia dalam waktu yang di tentukan.

o. Kerja kelompok berjalan dengan lancar, namun ada beberapa siswa yang masih mengandalkan kemampuan temannya, dan dia tidak ikut berpartisipasi dalam mengerjakan tugas yang sudah dibagikan oleh ketua kelompok. Namun guru selalu berkeliling untuk mengawasi jalannya kerja kelompok. Mulailah siswa semakin aktif dan begitu tekun dalam mengerjakan tugasnya.

p. Jam pelajaran akan segera habis, tetapi masih banyak kelompok yang belum selesai, maka guru memberikan kesempatan untuk dikerjakan pada pertemuan ke-dua.

q. Guru menutup pertemuan.

Pertemuan kedua dalam siklus II dilakukan pada hari Rabu, 03 mei 2017 pukul 09.15 WIB : a. Guru memasuki kelas dengan mengucapkan salam.

b. Salah satu siswa menyiapkan dan memimpin doa bersama.

c. Guru mengabsen kehadiran siswa,

d. Guru melakukan apersepsi, untuk mengetahui seberapa besar siswa memahami materi yang akan diberikan.

e. Guru memberikan kesempatan kepada siswa untuk bertanya mengenai materi sebelumnya yang telah dipelajari.

f. Siswa menanyakan tentang apa saja yang termasuk hutang jangka pendek.

g. Guru memberikan kesempatan kepada salah satu siswa untuk menjawab pertanyaan temannya, dan kemudian menyimpulkan dan menjelaskan kembali jawaban yang diberikan oleh temannya.

h. Guru memulai pembelajaran dengan mengatur tempat duduk siswa untuk berdekatan dengan kelompoknya.

i. Siswa melanjutkan mengerjakan tugas kelompok pertemuan sebelumnya.

j. Kerja kelompok berjalan dengan lancar dan guru selalu mengawasi dan menanyakan kesulitan dalam mengerjakannya.

k. Setelah semua kelompok telah selessai ngerjakan, salah satu kelompok mempersentasikaan hasil jawaban yang cocok dengan soal yang diberikan. 
1. Siswa diberikan kesempatan untuk sesi tanya jawab.

m. Guru menyimpulkan dan menjelaskan kembali jawaban yang telah dijawab oleh siswa.

n. Guru meminta kepada semua kelompok untuk mengumpulkan hasil kerja kelompoknya.

o. Guru meminta siswa untuk kembali ketempat duduk asal dan merapihkan tempat duduknya.

p. Sebelum menutup pertemuan, guru menyimpulkan dan mengoreksi hasil kerja kelompok, dan memberikan kesempatan kepada siswa untuk bertanya.

q. Guru memberitahu skenario pembelajaran pada pertemuan berikutnya.

r. Guru menutup pertemuan.

\section{Tabel.4 hasil post test siklus II}

\begin{tabular}{ccc}
\hline No & Nama & Post Test \\
1 & AAS & 90 \\
2 & CS & 95 \\
3 & DAS & 90 \\
4 & DS & 80 \\
5 & EY & 90 \\
6 & FR & 85 \\
7 & HF & 85 \\
8 & HL & 95 \\
9 & HR & 85 \\
10 & IH & 90 \\
11 & LTP & 85 \\
12 & LR & 95 \\
13 & LF & 90 \\
\hline & &
\end{tabular}

\begin{tabular}{ccc}
\hline 14 & MAE & 95 \\
15 & MA & 90 \\
16 & MAU & 90 \\
17 & MMS & 95 \\
18 & MAF & 90 \\
19 & MZI & 85 \\
20 & MU & 95 \\
21 & NM & 100 \\
22 & NUR & 95 \\
23 & NUH & 95 \\
24 & PIP & 90 \\
25 & RH & 90 \\
26 & RO & 85 \\
27 & RS & 90 \\
28 & SA & 100 \\
29 & SAN & 85 \\
30 & SB & 100 \\
31 & SM & 90 \\
32 & SMU & 85 \\
33 & SR & 85 \\
34 & SW & 90 \\
35 & SWA & 90 \\
36 & SU & 90 \\
37 & VR & 90 \\
38 & YS & 95 \\
39 & DS & 80 \\
& Jumlah & 3.52 \\
& Rata-Rata & 90,25 \\
\hline Sumber: Data yang diolah 2017
\end{tabular}

Menghitung nilai rata-rata kelas

Rata-rata nilai kelas post test $=$

Jumlah nilai akhiryang diperoleh siswa

Jumlah siswa

$=\quad 3.520 / 39$

$=90,25$ 
Tabel 5. Kriteria keberhasilan belajar siswa

\begin{tabular}{cc}
\hline Presentase & Kategori \\
\hline $91-100$ & Sangat baik \\
$81-90$ & Baik \\
$75-80$ & Cukup \\
$61-74$ & Kurang \\
$50-60$ & Sangat kurang \\
\hline
\end{tabular}

Apabila data nilai hasil post test siswa diatas dikelompokkan berdasarkan kriteria keberhasilan sebagaimana telah ditetapkan diawal, maka dapat diketahui bahwa nilai terendah yang diperoleh siswa adalah sebesar 80 dan nilai tertinggi 100 . Berdasarkan tabel tersebut rata-rata nilai yang dicapai pada post test dalam siklus II mencapai $90 \%$. Hal ini mengidentifikasikan bahwa proses pembelajaran yang dilaksanakan masuk ke dalam kategori Baik

Rumus Menghitung Ketuntasan Belajar

$$
\begin{aligned}
\mathrm{P} & =\sum \mathbf{P} \times 100 \% \\
\mathrm{P}= & \underline{3 \mathbf{N}} \times 100 \% \\
& 39 \\
= & 85 \%
\end{aligned}
$$

Keterangan :

$\mathrm{P}=$ Ketuntasan belajar

$\sum \mathrm{P}=$ Jumlah siswa yang tuntas belajar

$\sum \mathrm{N}=$ Jumlah siswa

$100 \%=$ Bilangan tetap

\section{3 . Observasi Siklus II}

Peneliti melakukan pengamatan proses pembelajaran dengan menggunakan media pembelajaran monopoli dikelas XI AK. Berdasarkan hasil pengamatan terhadap pelaksanaan proses pembelajaran akuntansi keuangan, diperoleh gambaran aktivitas siswa selama kegiatan belajar berlangsung, sebagai berikut :

Tabel 6. Lembar Observasi Siswa Siklus II

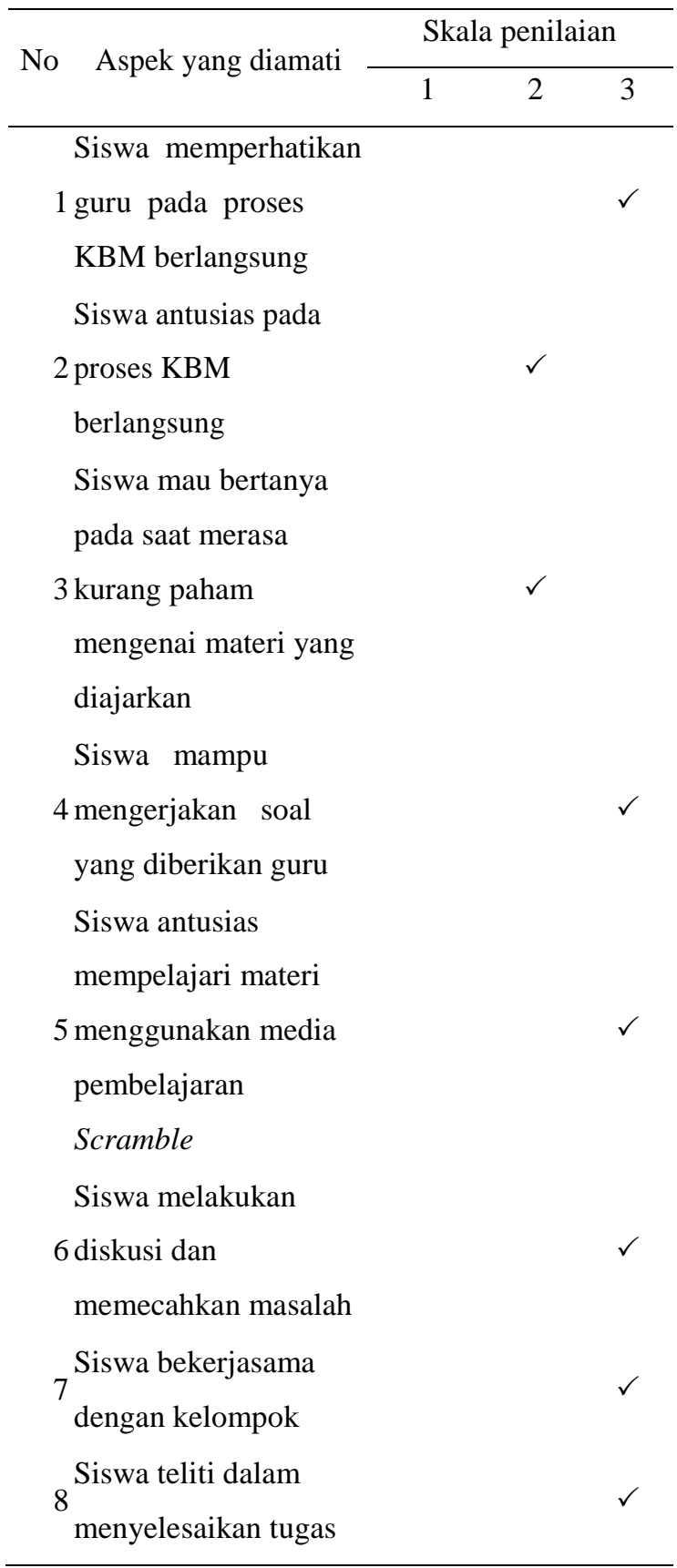


yang diberikan guru

Siswa lebih

9 bersemangat

mengikuti KBM

Siswa lebih aktif dan

10 jeli dalam proses

KBM

\begin{tabular}{lll}
\hline Jumlah & 6 & 21
\end{tabular}

Sumber: Data yang diolah 2017

Penilaian pada observasi menggunakan skala likert yaitu :

- $\quad$ Skor 1 : Kurang

- $\quad$ Skor 2 : Cukup

- $\quad$ Skor 3 : Baik

Tabel 7. Rubrik penilaian observasi siswa

\begin{tabular}{crl}
\hline Banyak Siswa & Skor & Keterangan \\
$0-15$ & Skor 1 & Kurang \\
$16-30$ & Skor 2 & Cukup \\
$31-40$ & Skor 3 & Baik
\end{tabular}

Kriteria Penilaian :

$81 \%-100 \%=$ Sangat baik

$71 \%-80 \%=$ Baik

$61 \%-70 \%=$ Cukup

$51 \%-60 \%=$ Kurang

Penilaian:

$\frac{\text { Jumlah skor }}{\text { Jumlah aspek } x \text { jumlah aspek tertinggi }} \times 100 \%$

$$
\begin{aligned}
& =\frac{27}{10 \times 3} \times 100 \% \\
& =90 \%
\end{aligned}
$$

Berdasarkan tabel 7, hasil pengamatan, aktivitas siswa mengalami peningkatan, aktivitas siswa pada siklus II 90\% yaitu berada pada kriteria A (Amat
Baik). Aktifitas siswa dari siklus I ke siklus II mengalami peningkatan sebesar $20 \%$.

Tabel 8. Lembar Observasi

No Aspek yang diamati \begin{tabular}{lll}
\hline \multirow{2}{*}{ Skala penilaian } \\
\cline { 2 - 4 }
\end{tabular}

Siswa memperhatikan

1 guru pada proses KBM

berlangsung

Siswa antusias pada proses

KBM berlangsung

Siswa mau bertanya pada

saat merasa kurang paham

mengenai materi yang

diajarkan

Siswa mampu

4 mengerjakan soal yang

diberikan guru

Siswa antusias

5 mempelajari materi

menggunakan media

pembelajaran Scramble

Siswa melakukan diskusi

6

dan memecahkan masalah

Siswa bekerjasama dengan

kelompok

Siswa teliti dalam

8 menyelesaikan tugas yang

diberikan guru

Siswa lebih bersemangat

9

10

mengikuti KBM

Siswa lebih aktif dan jeli dalam proses KBM

Jumlah

$6 \quad 21$

Sumber: Data yang diolah 2017 
Penilaian:

$$
\begin{aligned}
& \frac{\text { Jumlah skor }}{\text { Jumlah aspek } \times \text { jumlah aspek tertinggi }} \times 100 \% \\
& =\frac{27}{10 \times 3} \times 100 \% \\
& =90 \%
\end{aligned}
$$

Berdasarkan hasil pengamatan aktivitas guru, aktivitas guru pada siklus II 90\% yaitu berada pada kriteria A (Sangat Baik). Aktivitas guru mengalami peningkatan dari siklus I ke siklus II yaitu 17\%. Pada pertemuan ini guru melakukan pengelolaan kelas dengan baik dimulai dengan pengabsenan dan pemberian materi. Pada saat kegiatan belajar berlangsung siswa memperhatikan guru dalam menjelaskan materi, antusias pada proses KBM berlangsung dan bertanya mengenai materi yang masih belum dipahami. Pada pertemuan ini siswa mengikuti kegiatan pembelajaran lebih aktif dan jeli serta antusias mempelajari materi kartu hutang. Siswa mau bertanya pada saat merasa kurang paham mengenai materi yang disampaikan.

\section{Refleksi}

Setelah dilakukan tindakan dan evaluasi bentuk tes uji kompetensi, didapatkan rata-rata hasil belajar siswa dalam kelas 90,25\% berada dalam kategori sangat baik dan nilai siswa yang diatas KKM atau 80,00 sebanyak $100 \%$ atau 39 siswa, maka tindakan kelas dihentikan pada siklus II dengan alasan target telah tercapai.

Penerapan model pembelajaran Scramble merupakan penelitian tindakan kelas yang bertujuan untuk meningkatkan hasil belajar siswa pada mata pelajaran pengantar akuntansi dan keuangan. Penelitian ini dilakukan dengan dua siklus yaitu siklus I dan siklus II, dengan menggunakan model pembelajaran yang sama pada setiap siklusnya, yaitu model pembelajaran Scramble. Dari kedua siklus yang telah dilaksanakan terlihat adanya peningkatan hasil belajar siswa dengan menggunakan model pembelajaran scramble. Dan jumlah siswa yang mendapat nilai diatas KKM yaitu 75 juga semakin meningkat, hal ini dapat dilihat pada grafik dibawah ini :

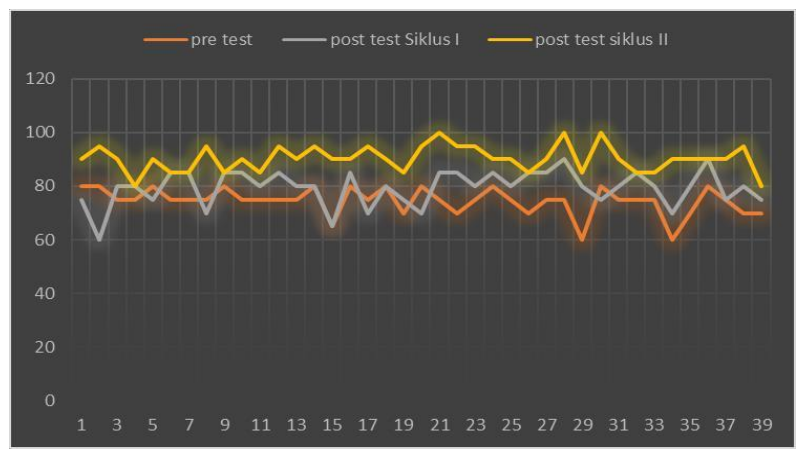

Gambar 2. Hasil evaluasi siklus I \& II

Berdasarkan grafik diatas dapat dilihat bahwa, pada siklus I siswa yang mendapat nilai diatas KKM yakni 75 sebanyak $86 \%$ atau 33 siswa dan $14 \%$ atau 
6 siswa masih mendapat nilai dibawah KKM. Sedangkan pada siklus II siswa yang mendapat nilai diatas KKM sebanyak $100 \%$ atau 39 siswa. Pelaksanaan pada siklus I karena siswa masih mengandalkan teman-temannya yang dianggap lebih bisa dari dirinya, dan guru kurang memberikan pendekatan kepada siswa-siswa yang kurang aktif dan memberikan apresiasi kepada siswa yang aktif, dan pada siklus II guru memperbaikinya dengan cara memberi perhatian dan motivasi kepada seluruh siswa. Nilai rata-rata kelas pada siklus I dan siklus II juga mengalami peningkatan, hal ini dapat dilihat dari diagram dibawah ini :

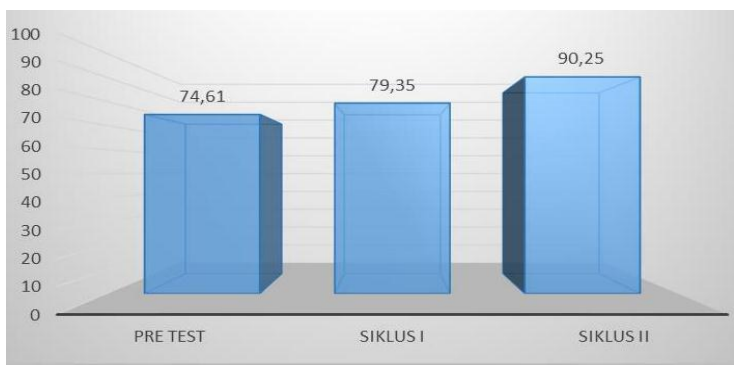

Gambar 3. Nilai Rata-rata kelas pada siklus 1 dan siklus 2

Berdasarkan pada diagram diatas, terlihat bahwa ada kenaikan nilai rata-rata kelas pada pre test, siklus I dan siklus II. Nilai rata-rata pre tes 74,61 siklus I adalah 79,35 sedangkan nilai rata-rata dalam kelas pada siklus 2 adalah 90,25. Ini berarti nilai rata-rata dalam kelas pada pre test dan post test siklus 1 mengalami kenaikan sebesar 4,74 sedangkan siklus I dan siklus II mengalami keniakan sebesar 10,90.
Dalam proses pembelajaran disekolah, pada hekekatnya yang berperan aktif adalah siswa, sedangkan guru berperan sebagai fasilitator. Peran guru sebagai pendidik harus bisa membangkitkan aktifitas siswa pada saat kegiatan pembelajaran dimulai, sehingga hasil belajar siswa dapat mencapai KKM (Kriteria Ketuntasan Minimum).

Keberhasilan pembelajaran mata pelajaran akuntansi keuangan dengan menerapkan model pembelajaran scramble dapat dilihat dari sebagai berikut :

1. Kegiatan belajar mengajar dikelas yang berpusat pada siswa (student active / student center) sehingga siswa aktif dalam proses pembelajaran baik dalam diskusi, kerja kelompok, presentasi dan tanya jawab. Kegiatan ini dapat melatih peserta didik dalam bekerja sama dan menumbuhkan semangat kebersamaan didalam kelompok belajar.

2. Siswa mampu memahami materi yang telah diberikan dan tidak akan cepat lupa dengan materi yang telah dipelajari. Hal ini terjadi karena siswa langsung merasakan ilustrasi transaksi yang terjadi, dan dapat dipraktekkan dalam kehidupan sehari-hari.

3. Hasil belajar siswa meningkat setelah mengikuti pembelajaran dengan menerapkan model pembelajaran scramble dan hasil belajar siswa 
dinyatakan tuntas, karena secara umum hasil belajar siswa mencapai KKM yaitu 75. Hal ini menunjukkan bahwa secara umum siswa telah memahami materi yang disajikan dengan baik pada kegiatan belajar mengajar dengan penerapan model pembelajaran scramble

\section{KESIMPULAN DAN SARAN}

Berdasarkan penelitian yang dilakukan diperoleh kesimpulan bahwa

1. Penerapan model pembelajaran Scramble dapat meningatkan hasil belajar siswa didalam kelas pada saat kegiatan belajar mengajar dimulai. Hasil observasi hasil belajar siswa pada siklus 1 sebesar $70 \%$ dan pada siklus 2 sebesar $90 \%$ terdapat peningkatan $30 \%$.

2. Penerapan model pembelajaran Scramble pada mata pelajaran akuntansi keuangan dapat meningkatkan hasil belajar siswa. Pada siklus 1 nilai rata-rata siswa dalam kelas adalah 79,35 sedangkan nilai rata-rata dalam kelas pada siklus 2 adalah 90,25. Ini berarti nilai rata-rata dalam kelas pada siklus 1 dan siklus 2 mengalami kenaikan sebesar 10,90. Selanjutnya dilihat dari presentase ketuntasan belajar siswa, pada siklus 1 memperoleh $85 \%$ meningkat menjadi $100 \%$ pada siklus 2. Peningkatan presentasi ketuntasan belajar siswa yang diperoleh pada siklus 1 dan siklus 2 sebesar $15 \%$.

Adapun saran dari penelitian ini adalah:

1. Hendaknya siswa dapat selalu aktif serta memiliki antusias menunjukkan partisipasinya dalam mengikuti kegiatan pembelajaran sehingga hasil belajar dapat meningkat .

2. Hendaknya siswa lebih meningkatkan keterampilan komunikasi yang baik, baik dengan guru maupun dengan sesama siswa, serta meningkatkan rasa percaya diri

3. Hendaknya guru lebih kreatif dalam menginovasi pembelajaran dan menggunakan model serta media pembelajaran yang aktif inovatif kreatif dan menarik serta menyenangkan sehingga menghasilkan pembelajaran yang berkualitas..

4. Guru lebih optimal dalam memanfaatkan sarana dan prasarana yang sudah disediakan oleh pihak sekolah sebagai alat bantu dalam mengembangkan media pembelajaran yang digunakan.

5. Sekolah, perlu menyediakan fasilitas penunjang yang mampu mendukung usaha pelaksanaan pembelajaran yang aktif, kreatif dan menyenangkan. 
6. Diharapkan adanya penelitian lebih lanjut untuk menilai aspek lain yang dapat ditingkatkan melalui model pembelajaran kooperatif tipe scramble

\section{DAFTAR PUSTAKA}

Arikunto, Suharsimi .(2013). Prosedur Penelitian suatu Pendekaan Praktek. Jakarta: Rineka Cipta.

Prosedur Penelitian Suatu Pendekatan Praktik. Edisi Revisi 6. Jakarta: Rineka Cipta

Huda, Miftahul. (2014). Model-model Pengajaran dan pembelajaran. Yogyakarta: Pustaka Pelajar.

Isjoni. (2007). Cooperative learning. Bandung: Alfabeta.

Kurniawan, Deni. (2014). Pembelajaran Terpadu Tematik: Teori, Praktik, dan Penilaian. Bandung : Alfabeta.

Purwanto, Ngalim. (2010). Psikologi pendidikan. Bandung: PT Remaja Rosda Karya.

Purwanto. (2014). Evaluasi Hasil Belajar, Surakarta: Pustaka Pelajar.

Solihatin, Etin. 2012. Strategi Pembelajaran. Jakarta: Bumi Aksara.

Cooperative Pembelajaran IPS. Jakarta: Bumi Aksara.

Sudjana, Nana. (2008). Penilaian Hasil Proses Belajar. Bandung: PT Remaja Rosdakarya

Suprijono, Agus. 2012. Cooverative Learning. Yogyakarta: Pustaka Pelajar.
UU No 20 Tahun 2003 Sistem Pendidikan Nasional.

Riyanto. 2010. Model Pembelajaran Kooperatif. [Online] Tersedia: http//kamriantiramli.wordpress.com/ 2011/07/19/model-pembelajarankooperatif-cooperative-learning/.

Widodo, Rachmat. 2010. Model Pembelajaran Scramble. Tersedia pada http://wyw1d.wordpress.com diakses pada tanggal 1 juli 2018. 